\title{
PROGRAM HUMANISASI: \\ Refleksi tentang Rehabilitasi Pelaku dan Korban Terorisme untuk Konteks Indonesia
}

\author{
Al Chaidar ${ }^{1}$, Herdi Sahrasad ${ }^{2}$, Iskandar Zulkarnaen ${ }^{3}$, Fauzi A. Rahman ${ }^{4}$, \\ Muntasir Abdul Kadir 5, Abdul Hadi Arifin 6 \\ 1 Program Studi Antropologi, Universitas Malikussaleh, Aceh-Indonesia \\ 2 Universitas Paramadina, Jakarta; Manajemen Freedom Foundation, Jakarta. \\ ${ }^{3}$ Program Ilmu Politik, Universitas Malikussaleh, Aceh-Indonesia. \\ ${ }^{4}$ Program Studi sosiologi, Universitas Malikussaleh, Aceh-Indonesia. \\ 5 Program Studi Ilmu Politik, Universitas Malikussaleh, Aceh-Indonesia. \\ ${ }^{5}$ Fakultas Ekonomi dan Bisnis, Universitas Malikussaleh, Aceh, Indonesia.
}

\begin{abstract}
Abstrak: Tak terhitung berapa rupiah materi dan pengorbanan lainnya yang dihabiskan untuk menanggulangi perkara terorisme melalui program deradikalisasi, sampai-sampai Polri dan BIN dituding berbagai kalangan sebagai lembaga yang sengaja membikin 'proyek terorisme' demi kelangsungan anggaran anti-terorisme milyaran rupiah/tahun. Harus disadari, dicamkan dan ditekankan bahwa dalam membasmi terorisme, negara dan masyarakat mesti seayun langkah dan bersatu. Tulisan ini menawarkan gagasan humanisasi sebagai bagian dari upaya deradikalisasi untuk menambal lubang-lubang yang bocor dari program yang sudah dilaksanakan. Dalam hal ini, humanisasi adalah respon untuk mencegah eskalasi kekerasan. Humanisasi mengakui martabat yang melekat pada manusia, mengakui kemanusiaan lawan-lawannya dan hak-hak asasi semua anggota keluarga manusia. Humanisasi memungkinkan orang mengenali karakteristik manusia yang dianggap musuh atau lawannya, sehingga dapat membantu orang untuk membatasi eskalasi kekerasan yang ekstrim. Humanisasi juga dapat membuka jalan bagi hubungan timbal balik dan keyakinan dalam kesetaraan manusia, menciptakan norma-norma bersama yang membatasi cara konflik tersebut dilancarkan.
\end{abstract}

Kata Kunci: deradikalisasi, terorisme, humanisasi 


\section{A. Pendahuluan}

Insiden Mako Brimob tahun 2018 yang menewaskan enam orang (lima diantaranya anggota kepolisian) dan serangan bom di tiga gereja di Surabaya bulan Mei $2018^{1}$ yang menewaskan sedikitnya 10 orang dan melukai lebih 40 warga, mengindikasikan secara tajam betapa terorisme sudah merasuki ruangruang keluarga secara masif. Dalam kasus serangan bom tiga gereja di Surabaya, seorang ibu yang mengenakan cadar dan rompi bersama dua anaknya terlibat dalam tindakan keji dan biadab tersebut. Sungguh miris dan menyentakkan!

Sudah trilyunan rupiah biaya dihabiskan untuk mencegah dan menanggulangi terorisme, sampai-sampai Polri dan BIN dituding berbagai kalangan sebagai lembaga yang sengaja membikin 'proyek terorisme' demi kelangsungan anggaran anti-terorisme milyaran rupiah/tahun, sungguh suatu tudingan yang menyakitkan, menyesatkan dan tidak berdasar karena bisa menimbulkan krisis kepercayaan di kalangan masyarakat dan demoralisasi di lingkungan kepolisian - Harus disadari, dicamkan dan ditekankan bahwa dalam membasmi terorisme, negara dan masyarakat musti bahu-membahu dan bersatu melawan terorisme, mengatasi, menaggulangi, menundukkan, dan memberantasnya! Maraknya aksi terorisme hari-hari ini membuat publik bertanya: Sejauh mana program deradikalisasi? Mengapa malah berbagai kelompok masyarakat makin radikal dan berani melawan aparat/petugas yang menggalakkan program deradikalisasi?

Sebagai gagasan awal untuk menutup dan mengatasi lubang-lubang kelemahan Program Deradikalisasi, penulis menyampaikan gagasan pentingnya program Humanisasi. Di sini, humanisasi adalah respon untuk mencegah eskalasi kekerasan. Humanisasi mengakui martabat yang melekat pada manusia, mengakui kemanusiaan lawan-lawannya dan hak-hak asasi semua anggota keluarga manusia. Humanisasi memungkinkan orang mengenali karakteristik manusia yang dianggap musuh atau lawannya, sehingga dapat membantu orang untuk membatasi eskalasi kekerasan yang ekstrim. Selama konflik atau ketegangan sosial berkepanjangan, perasaan kebencian intens dan keterasingan sering timbul antara pihak-pihak yang terlibat, maka humanisasi sangat diperlukan untuk mencegah atau menghadang

${ }^{1}$ Lihat, Kompas, 13/5/18; Jawa Pos, 13 Mei 2018; Media Indonesia, 14 Mei 2018; Republika, 14 Mei 2018. 
perbuatan dehumanisasi yang berwajah kekerasan fisik tersebut. Humanisasi mengarah pada pencegahan atau penanggulangan intensifikasi konflik dan eskalasi kekerasan, menutup jalan bagi pelanggaran hak asasi manusia atau tindakan genosida. Humanisasi mengacu pada strategi yang dirancang untuk meredam dinamika konflik yang destruktif dan berwajah kekerasan, terutama terorisme sebagai puncak dari radikalisme (Maiese, 2003).

Humanisasi dapat membantu orang (teroris) untuk memberikan gambaran manusiawi mengenai musuh atau lawannya yang dianggapnya sebagai manusia yang memiliki keburukan atau stereotip tertentu. Setelah lawan dipandang orang (teroris) bukan sebagai raksasa jahat atau berhala busuk, tapi layaknya sesama manusia yang memiliki pertimbangan moral dan nurani, maka konflik dapat dibingkai kembali dengan cara yang lebih produktif atau kreatif (Hamburg, 1998). Dengan menekankan pada kekuatan humanisasi yang mengandalkan pendekatan persuasif dan pendekatan intelektual-moral-material dalam bingkai kemanusiaan untuk menanggulangi terorisme, hal itu dapat menjadi sumbangsih bagi pemerintahan Presiden Joko Widodo dalam memberantas terorisme. Penting bagi pemerintahan Jokowi untuk mengedepankan pendekatan humanisasi guna melengkapi atau bahkan mengganti program deradikalisi. Sehingga bisa membuka harapan dan perspektif baru untuk menyadarkan para teroris pemula maupun teroris kelas berat/kakap agar kembali ke masyarakat dan kembali ke pangkuan ibu pertiwi yang menangis, sekaligus menghindari jatuhnya korban lebih banyak lagi.

Dewasa ini, Kementerian Dalam Negeri, Kementerian Agama, Badan Nasional Pemberantasan Terorisme (BNPT), dan Badan Intelijen Negara (BIN) masih menggunakan Program Deradikalisasi sebagai program rehabilitasi nonklinis. Namun, program tersebut tidak terpadu satu sama lain. Malahan Badan Nasional Penanggulangan Terorisme (BNPT) seringkali membantah program deradikalisasi ini telah gagal.

Namun ada baiknya BNPT dan BIN menelaah kajian Sidney Jones (2015) yang menyebutkan empat alasan lemah dan gagalnya program deradikalisasi di Indonesia. Pertama, meskipun gagasan bahwa mantan radikal memiliki kredibilitas untuk mempengaruhi kaum radikal lainnya masuk akal, upaya ini sangat terbatas 
keberhasilannya. Kaum radikal yang dikenal telah bekerja sama dengan polisi akhirnya dideskreditkan oleh kelompoknya. Kedua, program rehabilitasi yang didanai pemerintah untuk menangani para jihadis yang dibebaskan dari penjara terbukti gagal. Kaum radikal tidak memiliki keterampilan, tidak ada pekerjaan, dan akhirnya kembali ke lingkaran militan yang mereka kenal. Ketiga, kurangnya anggaran resmi untuk program deradikalisasi sehingga karena kesulitan keuangan, polisi gagal untuk memenuhi janji-janji untuk bantuan yang telah mereka janjikan kepada kelompok radikal. Akibatnya, kaum teroris kecewa dan tidak lagi tertarik memberikan informasi. Keempat, sistem penjara Indonesia yang korup telah terbukti merusak program deradikalisasi. Program Deradikalisasi yang mengandalkan pada perubahan ideologi semata, tidak lagi dianggap efektif mengatasi persoalan radikalisme dan terorisme.

Sebaliknya, dengan pendekatan Humanisasi, pemerintah Jokowi bisa menunjukkan humanisasi nyata berdasarkan Pancasila (ideologi negara) dalam menangani teroris yang memegang ideologi ekstrim sebagai alternatif untuk mengacaukan negara. Pendekatan ini mendayagunakan "intelektualisme" karena kaum teroris umumnya anti-intelektualisme, bervisi sempit, bersumbu pendek, berwatak doktriner-dogmatis dan berideologi radikal dengan pemahaman dangkal. Humanisasi juga bisa membatalkan asumsi para teroris bahwa pemerintah ingin agar mereka dibunuh atau ditangkap, sehingga dalam persepsi mereka hanya ada satu pilihan: untuk melawan, membunuh atau dibunuh.

Hemat penulis, pendekatan humanisasi bagi kaum teroris bisa membuka jendela harapan bagi mereka untuk meletakkan "senjata ideologinya" dan menyerah serta kembali ke masyarakat. Sehingga hal itu memungkinkan bagi kaum teroris memiliki perasaan dan kesadaran baru bahwa di masa depan, mereka bukanlah warga negara yang terkutuk dan tercela. Dengan humanisasi, stigma negative kepada para teroris bisa ditangga;kan, dan para teroris yang sudah lepas dari penjara akan merasa mereka bukan lagi musuh negara yang harus dihancurkan atau dibasmi selamanya.

Dengan pendekatan bijak dan manusiawi dari pemerintahan Jokowi, melalui keloga, keluarga, jaringan dan relasi mereka yang sudah bertobat dan meninggalkan ekstremisme, para teroris itu bisa membuka dialog dengan pejabat 
Aceh Anthropological Journal, Vol. 3, No. 1, hlm: 1-20, April 2019

yang berwenang tentang apa yang mereka inginkan dan apa yang mereka butuhkan selepas dari penjara agar bermanfaat dan bermakna di masyarakat.

Dalam menangani terorisme, sejauh ini humanisasi jarang ditemukan dibandingkan Program Deradikalisasi. Dengan insiden Mako Brimob dan serangan tiga gereja di Surabaya, saya percaya inilah momentum, inilah saatnya untuk menggunakan humanisasi dalam menangani terorisme yang yang tidak kunjung berakhir atau berhenti.

Memerangi terorisme harus dilakukan dengan berbagai cara dan metode, dan Program Humanisasi merupakan pendekatan yang relevan dan penting untuk melengkapi Program Deradikalisasi karena menempatkan prioritas pada sisi kemanusiaan dan intelektualisme. Kekerasan tidak harus diselesaikan dengan kekerasan, mengacu pada pandangan Mahatma Gandhi dan Johan Galtung. Untuk sebagian, alasan sosiologis- ideologis mengapa humanisasi dibutuhkan dalam menanggulangi terorisme di negeri ini adalah sebagai berikut:

Pertama, Para teroris adalah anak-anak bangsa yang "untuk sementara atau untuk waktu yang lama" tidak percaya terhadap Pancasila, kecewa dan frustrasi pada Negara Kesatuan Republik Indonesia (NKRI) yang secara simplistis dianggap sebagai Rezim Thogut. Kaum muda-mudi radikal ini celakanya menemukan ideologi ekstrim dan menyimpang dari internet dan media sosial, dari para 'mentor atau gurunya', yang membuat mereka menempuh jalan sesat sehingga menyimpang dan salah dalam menafsirkan Al-Quran atau ajaran Islam karena metode dan tafsir para 'mentor atau guru' mereka yang memang ekstrim. Oleh sebab itu, mereka membutuhkan pencerahan dan memerlukan Islam peradaban yang membuka cakrawala. Sebagai manusia berideologis ektrim, mereka membutuhkan lingkungan baru dan teman-teman baru, mengenal tentang perbedaan, pluralisme dan multikulturalisme. Humanisasi membukakan pintu ke arah itu.

Kedua, Harus dipahami bahwa narapidana dalam kasus terorisme perlu dibantu untuk melepaskan diri atau melarikan diri dari jaringan lama atau kelompok lama mereka. Langkah ini, jika disertai pendekatan humanisasi, diyakini menjadi langkah de-radikalisasi yang efektif. Tanpa program pelepasan mereka 
dari kelompok lama dan jaringan lama, narapidana terorisme akan sulit untuk melepaskan diri dari jaringan berbahaya dan ekstrim itu.

Sudah terbukti, ketidakmampuan keluarga, masyarakat terdekat dan pemerintah untuk melepaskan para bekas teroris dengan jaringan lama dan kelompok radikal lama, telah berkontribusi pada kegagalan program deradikaisasi. Buktinya, sejumlah mantan narapidana terorisme tetap menjadi radikal, bahkan lebih berbahaya ketika mereka keluar dari penjara yang diopenuhi dengan program dan visi-misi deradikalisasi.

Ketiga, Narapidana kasus terorisme harus diperkenalkan oleh keluarga dan teman-teman terdekat serta komunitas terdekat, dengan kebhinekaan, kemajemukan dan kelompok-kelompok yang berbeda, sampai kehadiran mereka yang berbeda itu bisa menjadi bagian penting dalam persepsi, pandangan dan sikap hidup para bekas teroris tersebut. Sekali lagi, ini kita sebut Program Humanisasi, di mana bersama keluarga, teman-teman dan komunitas terdekat, jiwa humanis dan inklusif para mantan teroris itu harus ditumbuhkan kembali karena mereka umumnya memiliki pandangan atau pemahaman yang keliru terhadap manusia lain dan kelompok yang berbeda.

Keempat, Humanisasi dapat dilakukan melalui dialog intensif dan pengenalan budaya atau kelompok yang berbeda dari mereka (teroris). Kekerasan lebih mudah dihadapi dengan kelembutan dan cinta, ketimbang dengan kekerasan dan kebencian itu sendiri. Dengan kata lain, program humanisasi dapat membantu para teroris membebaskan diri dari mental dan mindset lama setelah mereka lepas dari penjara, agar menjadi manusia baru yang bebas dan merdeka, lepas dari jaringan lama, beban suasana lama dan ideologi lama.

Salah satu program humanisasi adalah mendidik dan mengajarkan para narapidana terorisme untuk berdialog-bersosialisasi dengan keluarga, temanteman dan komunitas terdekat, tidak hanya dengan ulama, akademisi dan tokoh masyarakat. Dan juga perlunya pelatihan untuk menghasilkan berbagai hal yang produktif, membawa para pelaku teror kepada para korban terorisme dan memasuki pemahaman baru mengenai pluralisme dan multikulturalisme dengan "bahasa" yang mereka pahami, sesuai dengan nilai-nilai dan cara-cara "budaya" mereka. 
Pertemuan antara para tahanan dan korban terorisme menjadi salah satu cara untuk menyentuh hati mereka, dan dharapkan membuat mereka sadar bahwa tindakan mereka telah menyebabkan penderitaan bagi orang lain. Dalam hal ini, untuk mencegah penyebaran pemahaman radikal di penjara, adalah penting untuk membuat segregasi nerapidana terorisme dengan narapidana lain sesegera mungkin.

\section{B. Pembahasan}

\section{Kegagalan Deradikalisasi?}

Ada baiknya kita juga belajar dari berbagai negara dalam mensukseskan program penanggulangan terorisme, misalnya dari gagasan dan pengalaman di Jerman dan Australia meski berbeda secara sosial-budaya Jerman mengadopsi pendekatan humanisasi dengan mengandalkan keluarga dan teman-teman narapidana Neo-Nazi dan para teroris/radikalis. Pendekatan itu pertama kali digunakan pada kelompok neo-Nazi, dengan menyimpulkan bahwa orang-orang berideologi garis keras, radikal dan ekstrim tidak dapat di-deradikalisasi melalui kekuatan koersi dan kooptasi, melainkan oleh daya bujuk dan kelembutan/kehangatan dari keluarga dan teman-teman dekat mereka sendiri.

Di Australia, Ahli Kontra Terorisme Dr Anne Aly dari Edith Cowan University Australia mengungkapkan, deradikalisasi sebagian besar telah diprogram secara luas, dengan pencegahan melalui peningkatan kohesi sosial seperti pendidikan multikulturalisme dan pluralisme, pendekatan kekeluargaan bagi narapidana teroris secara informal, hibah untuk kompetisi olahraga, pemberdayaan keluarga teroris/narapidana teroris dan pelatihan/seminar kepemimpinan inklusif. Studi oleh Universitas Nasional Australia dan Pusat Riset Terorisme Global menemukan fakta upaya deradikalisasi itu telah "gagal untuk mencapai target bagi mereka yang paling membutuhkan bantuan". Dan, baru setelah melakukan pendekatan humanis (Humanisasi, istilah penulis), dengan mendayagunakan keluarga dan orang-orang yang paling dekat dengan subjek terorisme dan perilaku antisosial, program penuntasan terorisme pasca pemenjaraan itu bisa membuahkan hasil. Humanisasi membuat narapadana teroris bisa melepaskan diri dari belenggu keputus-asaan dan keterkucilan/isolasi sosial. 
Di Australia, keterlibatan dari imam penjara dan psikolog dibutuhkan, namun hal itu tidak cukup, sehingga focus utama tetap pada unit keluarga. Bahkan di Australia, kontributor kunci untuk haumanisasi adalah keluarga, teman-teman dekat dan handai taulan para mantan teroris itu sendiri. Itulah sebabnya unit keluarga, teman-teman dekat dan handai taulan sangat penting dalam Program Humanisasi, Peran keluarga, handai taulan dan teman-teman terdekat menjadi sangat relevan dan signifikan, untuk program Humanisasi sekaligus mengatasi "lubang-lubang kelemahan" deradikalisasi yang dianggap kontroversial dan gagal.

Insiden Mako Brimob dan serangan tiga gereja di Surabaya harus jadi "momentum sosial dan historis" untuk mengiimplementasikan program Humanisasi dan mengakui kegagalan program deradikalisasi. Dengan cara ini, diharapkan, setelah narapidana teroris bebas dari penjara, terpidana teroris tidak lagi kembali ke perilaku lama dan hubungan lama yang menjerumuskan mereka ke dalam lingkungan kekerasan dan dunia teror yang tak berkesudahan.

Itulah sebabnya pendekatan "Deradikalisasi" yang kontroversial sebaiknya tidak lagi ditonjolkan. Pasca insiden Mako Brimob dan serangan Gereja di Surabaya, ada momentum bagi Program Humanisasi yang telah tiba, dan itu sudah saatnya. Dalam program humanisasi ini, bagaimanapun, tentu ada kekurangan yang sebaiknya diperbaiki dan disempurnakan setelah prosesi dan implementasinya berjalan. Tentu saja keberhasilan pendekatan Humanisasi ini juga tergantung pada kesanggupan/komitmen pemerintah dan masyarakat yang perduli dalam menanggulangi terorisme, dengan mempertimbangkan kecenderungan, latar sosialkultural, tabiat dan karakter tiap teroris itu sendiri. Dengan menimbang kelemahan atau kegagalan Deradikalisasi, maka program Humanisasi pantas dipertimbangkan pemerintah karena dapat memperkuat kebijakan negara dalam mencegah, menindak dan memberantas terorisme secara terukur, komprehensif, beradab dan tepat guna.

\section{Humanisasi sebagai Respon untuk Mencegah Eskalasi Kekerasan}

Manusia biasanya tidak membunuh manusia lainnya. Manusia bahwa kita berniat untuk membunuh, menghilangkan, atau melakukan genosida terhadap harus manusiawi, dikeluarkan dari komunitas moral. Humanisasi adalah masalah melawan efek ini. Humanisasi adalah respon untuk mencegah eskalasi 
kekerasan. Humanisasi mengakui martabat yang melekat pada manusia, mengakui kemanusiaan lawan-lawannya dan hak-hak asasi semua anggota keluarga manusia. Humanisasi memungkinkan orang mengenali karakteristik manusia yang dianggap musuh atau lawannya, sehingga dapat membantu orang untuk membatasi eskalasi kekerasan yang ekstrim. Selama konflik atau ketegangan sosial berkepanjangan, perasaan kebencian intens dan keterasingan sering timbul antara pihak-pihak yang terlibat, maka humanisasi sangat diperlukan untuk mencegah atau menghadang perbuatan dehumanisasi yang berwajah kekerasan fisik tersebut (Maiese, 2003).

Melalui Menteri Koordinator Politik, Hukum dan Keamanan Luhut Binsar Pandjaitan, pemerintah Joko Widodo sedang mempertimbangkan untuk memberikan grasi ke seluruh anggota kelompok Santoso pada kondisi menyerah. Sebelumnya, amnesti juga dijanjikan untuk Minimi Din, mantan pemimpin kelompok bersenjata di Aceh, yang menyerah. (Kompas, 22/7/16). Dengan menekankan pada kekuatan persuasif dalam menanggulangi terorisme, hal itu menjadi bukti bahwa pemerintahan Presiden Joko Widodo mengedepankan pendekatan humanis untuk melengkapi program deradikalisi, sehingga bisa membuka harapan untuk menyadarkan para teroris di Poso dan daerah lainnya untuk kembali ke pelukan ibu pertiwi, seraya menghindari jatuhnya korban lebih banyak lagi.

Dengan pendekatan humanis, pemerintah Jokowi telah menunjukkan humanisasi nyata berdasarkan Pancasila (ideologi negara) dalam menangani teroris yang memegang ideologi ekstrim sebagai alternatif untuk mengacaukan negara. Pendekatan ini mendayagunakan "intelektualisme" karena kaum teroris umumnya anti-intelektualisme, berwatak doktriner dan berideologi radikal dengan pemahaman dangkal. Humanisasi juga bisa membatalkan asumsi para teroris bahwa pemerintah ingin agar mereka dibunuh atau ditangkap, sehingga dalam persepsi mereka hanya ada satu pilihan: untuk melawan, membunuh atau dibunuh.

Pendekatan humanis bagi teroris Poso ini, bisa membuka jendela harapan bagi mereka untuk turun gunung dan menyerah. Dan, adalah mungkin bahwa di masa depan, mereka tidak merasa sebagai warga negara terkutuk dan tercela, dikecam sebagai musuh negara yang harus dihancurkan atau dibasmi selamanya. Menanggapi pendekatan bijak dan manusiawi dari pemerintahan Jokowi, para 
teroris itu, melalui keluarga, jaringan dan relasi mereka yang sudah bertobat dan meninggalkan ekstremisme, bisa juga membuka dialog dengan pejabat yang berwenang tentang apa yang mereka inginkan dan apa yang mereka butuhkan sebelum menyerah, turun gunung.

Dalam menangani terorisme, sejauh ini humanisasi jarang ditemukan dibandingkan Program Deradikalisasi dan inilah saatnya untuk menggunakan humanisasi dalam menangani terorisme yang yang tidak kunjung berakhir atau berhenti. Memerangi terorisme harus dilakukan dengan berbagai cara dan metode, dan Program Humanisasi merupakan pendekatan yang relevan dan penting untuk melengkapi Program Deradikalisasi karena menempatkan prioritas pada sisi kemanusiaan dan intelektualisme. Kekerasan tidak harus diselesaikan dengan kekerasan, mengacu pada pandangan Mahatma Gandhi dan Johan Galtung. Dan itulah alasan praktisnya, mengapa humanisasi dibutuhkan dalam menanggulangi terorisme di negeri ini.

Para teroris adalah anak-anak bangsa yang "untuk sementara" tidak percaya terhadap Pancasila, kecewa dan frustrasi, yang celakanya menemukan ideologi ekstrim dan menyimpang, menempuh jalan sesat dan salah menafsirkan Al-Quran atau Kitab Suci. Mereka membutuhkan pencerahan dan memerlukan Islam peradaban yang membuka cakrawala. Sebagai manusia berideologis ektrim, mereka membutuhkan lingkungan baru dan teman-teman baru, mengenal tentang perbedaan, pluralisme dan multikulturalisme. Humanisasi membukakan pintu untuk itu.

Harus dipahami bahwa narapidana dalam kasus terorisme perlu dibantu untuk melepaskan diri atau melarikan diri dari jaringan lama atau kelompok lama mereka. Langkah ini, jika disertai pendekatan humanis, diyakini menjadi langkah de-radikalisasi yang efektif. Tanpa program pelepasan mereka dari kelompok lama dan jaringan lama, narapidana terorisme akan sulit untuk melepaskan diri dari jaringan berbahaya dan ekstrim itu. Sudah terbukti, ketidakmampuan keluarga, masyarakat terdekat dan pemerintah untuk melepaskan para bekas teroris dengan jaringan lama dan kelompok radikal lama, telah berkontribusi pada kegagalan program deradikaisasi. Buktinya, sejumlah mantan narapidana terorisme tetap menjadi radikal, bahkan lebih berbahaya ketika mereka keluar dari penjara. 
Santoso Abu Wardah, pemimpin Mujahidin Indonesia Timur yang ditembak beberapa pekan lalu, juga Sunakim alias Afif, pelaku bom Thamrin, Jakarta Januari lalu, dan Bahrun Naim yang menjadi salah satu articulator ISIS (NIIS-Negara Islam di Irak dan SUriah), adalah narapidana binaan Program Deradikalisasi yang makin radikal dan menjadi-jadi setelah keluar dari penjara. Demikian juga Fadli Sadama, residivis aksi perampokan di Medan dan Aceh yang menggunakan hasil uangnya untuk melakukan aksi terorisme. Fadli Sadama sempat mengikuti program deradikalisasi yang dilakukan oleh pemerintah namun ia kemudian kembali melakukan terror (Alchaidar, 2016). Narapidana dalam kasus terorisme umumnya juga memiliki kebencian terhadap kelompok, atau pihak yang berbeda dari mereka. Oleh karena itu, humanisasi melalui keluarga dan teman-teman terdekat, seperti pengenalan budaya, pluralisme dan multikultualisme "dalam bahasa mereka" sangat relevan dan dibutuhkan.

Narapidana kasus terorisme harus diperkenalkan oleh keluarga dan temanteman terdekat serta komunitas terdekat, dengan kebhinekaan, kemajemukan dan kelompok-kelompok yang berbeda, sampai kehadiran mereka yang berbeda itu bisa menjadi bagian penting dalam persepsi, pandangan dan sikap hidup para bekas teroris tersebut. Sekali lagi, ini kita sebut Program Humanisasi, di mana bersama keluarga, teman-teman dan komunitas terdekat, jiwa humanis dan inklusif para mantan teroris itu harus ditumbuhkan kembali karena mereka umumnya memiliki pandangan atau pemahaman yang keliru terhadap manusia lain dan kelompok yang berbeda.

Humanisasi dapat dilakukan melalui dialog intensif dan pengenalan budaya atau kelompok yang berbeda dari mereka (teroris). Kekerasan lebih mudah dihadapi dengan kelembutan dan cinta, ketimbang dengan kekerasan dan kebencian itu sendiri. Dengan kata lain, program humanisasi dapat membantu para teroris membebaskan diri dari mental dan mindset lama setelah mereka lepas dari penjara, agar menjadi manusia baru yang bebas dan merdeka, lepas dari jaringan lama, beban suasana lama dan ideologi lama.

Salah satu program humanisasi adalah mengajarkan para narapidana terorisme untuk berdialog-bersosialisasi dengan keluarga, teman-teman dan komunitas terdekat, tidak hanya dengan ulama, akademisi dan tokoh masyarakat. 
Dan juga perlunya pelatihan untuk menghasilkan berbagai hal yang produktif, membawa para pelaku teror kepada para korban terorisme dan memasuki pemahaman baru mengenai pluralisme dan multikulturalisme dengan "bahasa" yang mereka pahami, sesuai dengan nilai-nilai dan cara-cara "budaya" mereka.

Pertemuan antara para tahanan dan korban terorisme menjadi salah satu cara untuk menyentuh hati mereka, dan dharapkan membuat mereka sadar bahwa tindakan mereka telah menyebabkan penderitaan bagi orang lain. Dalam hal ini, untuk mencegah penyebaran pemahaman radikal di penjara, adalah penting untuk membuat segregasi nerapidana terorisme dengan narapidana lain sesegera mungkin. Dengan cara ini, diharapkan, setelah mereka bebas dari penjara, terpidana teroris tidak lagi kembali ke perilaku lama dan hubungan lama yang menjerumuskan mereka ke dalam lingkungan kekerasan dan dunia teror.

Dalam program humanisasi ini, bagaimanapun, tidak semua metode bekerja dengan hasil memuaskan, karena keberhasilan metode ini juga tergantung pada kecenderungan setiap teroris itu sendiri. Namun langkah humanisasi jelas bisa melengkapi deradikalisasi agar tepat guna, bermanfaat dan tidak sia-sia. Dewasa ini, Kementerian Dalam Negeri, Kementerian Agama, Badan Nasional Pemberantasan Terorisme (BNPT), dan Badan Intelijen Negara (BIN) masih menggunakan program deradikalisasi sebagai program rehabilitasi non-klinis. Namun, program tersebut tidak terpadu satu sama lain. Malahan Badan Nasional Penanggulangan Terorisme (BNPT) seringkali membantah program deradikalisasi ini gagal.

Ada baiknya BNPT dan BIN menelaah kajian Sidney Jones (2015) yang menyebutkan empat alasan lemah dan gagalnya program deradikalisasi di Indonesia. Pertama, meskipun gagasan bahwa mantan radikal memiliki kredibilitas untuk mempengaruhi kaum radikal lainnya masuk akal, upaya ini sangat terbatas keberhasilannya. Kaum radikal yang dikenal telah bekerja sama dengan polisi akhirnya dideskreditkan oleh kelompoknya. Kedua, program rehabilitasi yang didanai pemerintah untuk menangani para jihadis yang dibebaskan dari penjara terbukti gagal. Kaum radikal tidak memiliki keterampilan, tidak ada pekerjaan, dan akhirnya kembali ke lingkaran militan yang mereka kenal. Ketiga, kurangnya anggaran resmi untuk program deradikalisasi sehingga karena kesulitan keuangan, 
polisi gagal untuk memenuhi janji-janji untuk bantuan yang telah mereka janjikan kepada kelompok radikal. Akibatnya, kaum teroris kecewa dan tidak lagi tertarik memberikan informasi. Keempat, sistem penjara Indonesia yang korup telah terbukti merusak program deradikalisasi. Program deradikalisasi yang mengandalkan pada perubahan ideologi semata, tidak lagi dianggap efektif mengatasi persoalan radikalisme dan terorisme.

\section{Peran Keluarga dan Teman Dekat}

Yang paling krusial, dalam banyak kasus deradikalisasi, program itu menjadi rusak akibat kebijakan pemerintah yang dianggap keluarga mantan teroris sebagai anti-Islam, anti-Muslim dan juga akibat "konsultasi psikologis' yang melelahkan bagi para mantan teroris yang melihat upaya deradikalisasi itu sebagai tindakan yang tidak tulus, berbau kamuflase dan hipokrisi. Ada baiknya kita juga belajar dari berbagai negara dalam mensukseskan program deradikalisasi, misalnya, dari gagasan dan pengalaman di Jerman dan Australia serta Mesir.

Jerman mengadopsi pendekatan humanis dengan mengandalkan keluarga dan teman-teman narapidana Neo-Nazi dan para teroris/radikalis. Pendekatan itu pertama kali digunakan pada kelompok neo-Nazi, dengan menyimpulkan bahwa orang-orang berideologi garis keras, radikal dan ekstrim tidak dapat dideradikalisasi melalui kekuatan koersi dan kooptasi, melainkan oleh daya bujuk dan kelembutan/kehangatan dari keluarga dan teman-teman dekat mereka sendiri.

Di Australia, Ahli Kontra Terorisme Dr Anne Aly dari Edith Cowan University Australia mengungkapkan, deradikalisasi sebagian besar telah diprogram secara luas, dengan pencegahan melalui peningkatan kohesi sosial seperti pendidikan multikulturalisme dan pluralisme, hibah untuk kompetisi olahraga dan pelatihan/seminar kepemimpinan inklusif. Namun studi oleh Universitas Nasional Australia dan Pusat Riset Terorisme Global menemukan fakta upaya deradikalisasi itu telah "gagal untuk mencapai target bagi mereka yang paling membutuhkan bantuan". Dan, baru setelah melakukan pendekatan humanis (Humanisasi) dengan mendayagunakan keluarga dan orang-orang yang paling dekat dengan subjek terorisme dan perilaku antisosial, program deradikalisasi itu bisa membuahkan hasil. 
Di Australia, keterlibatan dari imam penjara dan psikolog dibutuhkan, namun hal itu tidak cukup, sehingga focus utama tetap pada unit keluarga. Bahkan di Australia, kontributor kunci untuk deradikalisasi (dan sebaliknya yakni radikalisasi), adalah keluarga para mantan teroris itu sendiri. Itulah sebabnya unit keluarga sangat penting dalam Program Humanisasi, Peran keluarga dan temanteman terdekat menjadi sangat relevan dan signifikan, untuk melengkapi deradikalisasi yang dianggap kontroversial dan gagal.

Di Mesir, selama periode 1980-an dan 1990-an, ada tiga kekuatan yang membuat deradikalisasi berbasis ideologi di Mesir berjalan efektif. Pertama, deradikalisasi menyentuh aspek doktrin keagamaan yang disampaikan hingga ruang-ruang keluarga para mantan teroris. Para tokoh Islam Mesir, terutama tokoh Jamaah Islamiyah (JI), memahami, sejumlah ajaran keagamaan telah disalahpahami oleh kelompok teroris-anarkis dan keluarga mereka serta menjadi "pegangan" mereka dalam menjalankan aksi berdarah tanpa merasa bersalah. Dalam konteks ini, deradikalisasi berbasis ideologi berhasil menghancurkan kekuatan utama kelompok teroris-anarkis dan meyakinkan keluarga mereka agar menjadi Muslim yang toleran, bajik dan benar.

Kedua, deradikalisasi Mesir hingga para teroris dan keluarganya itu dilengkapi dan diperkuat dengan kekuatan struktural, khususnya di internal JI Mesir. Hal karena deradikalisasi diprakarsai dan dilakukan oleh tokoh-tokoh spiritual JI, seperti Sheikh Najih Ibrahim Abdullah, Sheikh Ali Syarif, dan Sheikh Usamah Ibrahim Hafiz. Ketiga, otoritas ilmu keislaman. Sheikh Najih Ibrahim Abdullah, Sheikh Ali Syarif, Sheikh Usamah Ibrahim Hafiz, dan lainnya disegani karena mereka adalah tokoh dengan ilmu keislaman mumpuni, baik di internal JI maupun dalam konteks publik Mesir secara umum. Deradikalisasi bisa efektif karena melibatkan orang-orang yang menempati posisi puncak dalam struktur organisasi JI Mesir. Kekuatan struktural inilah yang mampu membawa gerbong keluarga JI Mesir untuk berjalan konsisten dengan isi maklumat deradikalisasi. (Hasibullah Satrawi, 2011).

Dewasa ini di bawah pemerintahan Abdel Fattah Saeed Hussein Khalil El-Sisi, mantan Panglima Angkatan Bersenjata Mesir yang berperan mengakhiri Presiden Islamis Mohamed Morsi, dan disahkan sebagai Presiden Mesir selepas Pilihan raya 
Presiden Mesir 2014 pada 29 Mei 2014, program deradikalisasi disertai humanisasi, difokuskan untuk menanggulangi dan mengatasi radikalisme kelompok Ikhwanul Muslimin (IM), mantan teroris dan keluarga mereka, dengan cara dan metode yang berdasarkan kondisi sosial dan kultural Mesir yang ada.

Sekali lagi, deradikalisasi seyogianya dilengkapi humanisasi karena butuh partisipasi tulus dan perhatian serius dari keluarga mantan teroris, teman/sahabat dan lingkungan masyarakat terdekatnya, karena mereka yang lebih tahu kebutuhan lahir-batin untuk para mantan teroris itu. Merekalah yang diperkirakan paling tahu langkah apa yang harus disesuaikan secara individu dan sosial bagi para mantan teroris dan radikalis, berdasarkan alasan-alasan yang beragam, guna mencegah para teroris dan radikalis itu kembali ke ekstremisme kekerasan.

Melihat musuh sebagai orang di luar komunitas di mana norma-norma moral berlaku, dapat mengurangi hambatan terhadap agresi dan mengurangi upaya melegitimasi kekerasan. Bahwa mengenali karakteristik lawan, seseorang dapat membantu untuk membatasi eskalasi dan kekerasan (Maiese, 2003).

Selama konflik atau ketegangan sosial berkepanjangan, perasaan kebencian intens dan keterasingan sering timbul antara pihak-pihak yang terlibat, maka humanisasi sangat diperkukan untuk mencegah atau menghadang perbuatan dehumanisasi yang berwajah kekerasan fisik. Orang mulai mendelegitimasi orang lain yang mereka rasakan sebagai ancaman besar bagi nilai-nilai kesejahteraan mereka (Deutsch, 2000). Melihat lawan sebagai jahat, menyimpang, atau pidana mungkin juga membenarkan agresi lebih lanjut atau kekerasan dan membuat tindakan yang tidak terpikirkan sebelumnya (Rubin and Pruitt, 1994). Dehumanisasi ini mengarah pada intensifikasi konflik dan eskalasi kekerasan, membuka jalan bagi pelanggaran hak asasi manusia yang berat atau tindakan genosida. Humanisasi mengacu pada strategi yang dirancang untuk melawan dinamis konflik destruktif ini.

\section{Strategi humanisasi}

Wawasan tambahan ke dalam humanisasi yang ditawarkan oleh beberapa peserta proyek bisa diperbaiki. Berbagai strategi dapat digunakan untuk memperbesar ruang lingkup komunitas moral seseorang. Misalnya, pihak pemerintah dapat menggunakan simulasi antar-kelompok untuk mengajarkan 
tentang stereotip dan permusuhan terhadap individu keluar-kelompok dan mendorong orang untuk mempertimbangkan perasaan orang-orang ini (Deutsch, 2000). Orang dapat menempatkan diri di tempat individu out-group melalui bermain peran, pembalikan peran, atau dipandu imajinasi. Semua ini metode asuh empati dan mendorong pihak lain untuk bersimpati, membayangkan bagaimana "musuh" mereka sendiri.

Empati juga dapat membantu pihak yang berselisih untuk melihat agresi masing-masing sebagai setidaknya sebagian mirip dengan mereka sendiri, reaktif termotivasi dan terhubung dengan kebutuhan dan nilai-nilai. Mengakui perspektif orang lain dapat menempatkan kebutuhan dan hak-hak orang lain dalam posisi untuk dipertimbangkan dan membuat sulit untuk melihat yang lain sebagai luar komunitas moral (Opotow, 1995). Karena kedua belah pihak mulai menyadari bahwa perilaku lain dimotivasi oleh keadaan yang kompleks, mereka akan lebih dilengkapi untuk membedakan antara tindakan buruk dan orang jahat (Rothman, 1997). Ketimbang memperlakukan lawan mereka sebagai monster yang tidak manusiawi dan mengerikan, mereka dapat mulai mengidentifikasi dengan mereka dalam beberapa cara.

Dalam kaitan ini, dialog juga dapat membantu memperdalam tingkat pemahaman antara kelompok-kelompok dalam konflik. Karena kedua belah pihak berbicara secara terbuka tentang motivasi konflik, menjadi jelas bahwa mereka memiliki "beberapa kendala situasional yang sama dan motivasi yang mendasari untuk memenuhi kebutuhan seperti keamanan, kontrol, dan identitas." (Rothman, 1997). Sebagai sebuah ketakutan umum, kebutuhan, dan motivasi yang ditemukan, cerita individu mulai bergabung menjadi satu bersama, cerita yang lebih besar. Ini semacam identifikasi dengan lawan seseorang menekankan kemanusiaan dari semua pihak dan mengurangi kemungkinan agresi kekerasan.

Kadang-kadang, berfokus pada kesamaan kepentingan dapat membawa mengakui kemanusiaan dari lawan. Humanisasi dapat terjadi melalui pertukaran informasi dan ide-ide dan penemuan tujuan bersama. Ini kadang-kadang dapat terjadi melalui lokakarya pemecahan masalah di mana pihak menemukan titik temu. Pihak mungkin juga mengembangkan super-ordinat, atau bersama, tujuan. tujuan tersebut dapat memiliki efek pemersatu yang kuat dan mengarah pada 
pembentukan, kelompok inklusif baru. Dengan membawa kelompok bersama-sama untuk mengejar keuntungan bersama yang hanya bisa didapatkan melalui kerja sama, tujuan super-ordinat dapat membantu pihak mulai menganggap diri mereka sebagai keluarga. Tujuan yang mungkin menghindari kehancuran nuklir, perlindungan lingkungan, kohesi sosial, dan proyek-proyek pembangunan masyarakat. Mengejar tujuan tersebut dapat membantu kita "belajar untuk memperluas identifikasi sosial kita dalam terang kepentingan bersama" di semua umat manusia (Hamburg, 1998).

Lintas Sektoral atau tumpang tindih keanggotaan grup yang menghubungkan negara-negara atau kelompok dari masyarakat juga dapat membantu pihak untuk mengenali manusia dari lawan mereka. Menyadari lawan yang satu ini adalah anggota dari beberapa kelompok yang lebih besar yang satu juga termasuk hasil dalam kesamaan persepsi, yang pada gilirannya dapat menimbulkan sentimen positif. ikatan sosial antara individu di kedua sisi konflik memungkinkan untuk humanisasi dan dapat membantu untuk memerangi polarisasi.

Misalnya, kontak yang baik di antara anggota kelompok yang berbeda dan negara-negara yang memungkinkan mereka untuk bekerja bersama-sama atau bermain bersama dapat meningkatkan rasa kemanusiaan bersama. pertukaran tersebut dapat pendidikan, budaya, atau ilmiah, dan mempromosikan kontak pribadi empatik dan saling menghormati (Hamburg, 1998).

Pendidikan juga dapat membantu untuk melawan efek negatif dari propaganda dan bantuan pihak mendekati mereka yang di luar kelompok mereka lebih konstruktif. Hal ini dapat membantu dalam humanisasi dengan menyampaikan gagasan bahwa kita semua adalah bagian dari luas, saling bergantung, keluarga di seluruh dunia "berbagi kesamaan dasar manusia." (Hamburg, tt). Sekolah juga dapat menumbuhkan perilaku kooperatif antara anakanak, mendorong mereka untuk menerima orang yang berbeda dari diri mereka sendiri dan mengakui bahwa mereka memiliki kebutuhan dan nilai-nilai yang sama dengan orang-orang dari dalam kelompok.

Media juga memiliki potensi humanisasi besar. Misalnya, program televisi dapat digunakan "untuk mengungkap musuh dan meningkatkan pemahaman." 
(Hamburg, tt). Pemrograman yang menyoroti penderitaan manusia dan konsekuensi dari agresi bisa membantu orang untuk mengenali korban mengerikan kekerasan yang mengambil orang kehidupan nyata. kekerasan lebih lanjut terhadap musuh mungkin datang dianggap sebagai tidak manusiawi.

\section{Kesimpulan}

Humanisasi dapat membantu untuk memecah gambar musuh atau stereotip merusak. Setelah lawan satu dipandang bukan sebagai rakasa jahat, tapi layak sesama manusia dari pertimbangan moral, konflik dapat dibingkai kembali dengan cara yang lebih produktif. Seperti yang disarankan di atas, humanisasi dapat membantu untuk de-meningkat konflik atau membatasi eskalasi, serta mengurangi kemungkinan kekerasan massal atau genosida. Pihak yang menganggap satu sama lain sebagai manusia akan merasa jauh lebih sulit untuk merasionalisasi taktik kasar atau mengabaikan norma-norma hak asasi manusia. Humanisasi juga dapat membuka jalan bagi hubungan timbal balik dan keyakinan dalam kesetaraan manusia, menciptakan norma-norma bersama yang membatasi cara konflik tersebut dilancarkan. Humanisasi dapat memungkinkan pihak untuk melihat bahwa bahkan lawan-lawan mereka yang layak pengobatan tersebut. Dengan demikian, dapat menjadi komponen penting dari transformasi konflik.

Freire menjelaskan proses ini di Pedagogi nya Kaum Tertindas (pertama kali diterbitkan pada tahun 1970) sebagai salah satu di mana "pria dan wanita mengembangkan kekuatan mereka untuk merasakan kritis cara mereka ada di dunia dengan yang dan di mana mereka menemukan diri mereka; mereka datang untuk melihat dunia tidak sebagai realitas statis tetapi sebagai sebuah realitas dalam proses transformasi. Kita menjadi diperbudak oleh ideologi dan perangkat kerasnya, kemudian akan menjadi dalam hal Freire proses dehumanisasi tersebut. Freire menjelaskan apa ini dan bagaimana hal ini kontras dengan di atas menjelaskan proses humanisasi dengan menggunakan metafora dari konsep perbankan. Makna berada di sini deposito kepada kita dalam pikiran kita, kita berada dalam proses ini konsumen pasif ide dari orang lain, kita tidak mempertanyakan, kami hanya menerima.

Dalam cara agama mengingatkan manusia tentang kemampuannya untuk membentuk realitas, untuk menjadi pencipta transformasi sendiri. Freire 
Aceh Anthropological Journal, Vol. 3, No. 1, hlm: 1-20, April 2019

mengatakan bahwa untuk memanusiakan, kita harus sadar bagaimana ideologi direproduksi dalam masyarakat, bagaimana kekuasaan dimainkan dan dipelihara dengan 'kata' (Freire and Macedo, 2003). Salah satu elemen penting dari pedagogi tentang pembebasan adalah bahwa kita harus sadar bahwa kita "membaca dunia dengan membaca kata".

Ketika kita menjadi sadar ini kita memasuki ranah literasi kritis. Ini adalah negara yang sedang berlangsung dan merupakan cara penting untuk menempatkan proses humanisasi kami dalam praktek. Kami mulai merangkul kemampuan manusia. Kami mendekati 'kata' sebagai wadah di mana makna telah tersimpan. Kami mengambil pendekatan kritis terhadap 'bagaimana', 'mengapa' dan lebih diskursif 'apa' yang kata membawa. Tidak heran agama dan morfologi (studi kata) memiliki asal etimologis umum. "Orang yang membentuk", kekuatan arti menghasilkan kata-kata. Mediasi pengalaman yang terjadi dalam tindakan sadar memilih kata yang tepat. 


\section{DAFTAR PUSTAKA}

Chaidar, Al., Blake Respini, Herdi Sahrasad. 2016. From Shariatism to Terrorism: Islam in Indonesia Post Authoritarian. Lhokseumawe: LSAF dan Unimal Press, 2016.

Deutsch, Morton. 2000. "Cooperation and Competition," in The Handbook of Conflict Resolution: Theory and Practice ed. M. Deutsch and P. Coleman. San Francisco: Jossey-Bass.

Deutsch, Morton. 2000. "Justice and Conflict," in The Handbook of Conflict Resolution: Theory and Practice, ed. Morton Deutsch and Peter Coleman. San Francisco: Jossey-Bass Publishers, Inc.

Freire, Paolo and Donaldo Macedo. 2003. "Rethinking literacy: A dialogue." The critical pedagogy reader.

Hamburg, David. "Education for Conflict Resolution," [article on-line] (The Carnegie Commission on Preventing Deadly Conflict) available from http://carnegie.org/fileadmin/Media/Publications/PDF/Education\%20for \%20Conflict\%20Resolution\%20Can\%20We\%20Learn\%20to\%20Live\%20 Together.pdf

Hamburg, David. 1998. "Preventing Contemporary Intergroup Violence," in The Handbook for Interethnic Coexistence, ed. Eugence Weiner. New York: Continuum Publishing, 1998,

Jawa Pos, 13 Mei 2018.

Kompas, Minggu,13/5/18.

Maiese, Michelle. 2003. "Humanization." Beyond Intractability. Eds. Guy Burgess and Heidi Burgess. Conflict Information Consortium, University of Colorado, Boulder.

Media Indonesia, 14 Mei 2018.

Opotow, Susan. 1995. "Drawing the Line: Social Categorization, Moral Exclusion, and the Scope of Justice," in Conflict, Cooperation and Justice: Essays Inspired by the Work of Morton Deutsch, ed. Morton Deutsch, Barbara Bunker, and Jeffrey Rubin. San Francisco: Jossey-Bass.

Republika, 14 Mei 2018.

Rothman, Jay. 1997. Resolving Identity-Based Conflict in Nations, Organizations, and Communities. San Francisco: Jossey-Bass Publishers.

Rubin, Jeffrey Z. and Dean G. Pruitt. 1994. Social Conflict: Escalation, Stalemate, and Settlement, 2nd edition. New York: McGraw Hill College Division. 